\title{
Penggunaan Open Ended untuk Meningkatkan Kreativitas Belajar Mahasiswa pada Mata Kuliah Konsep Dasar IPA
}

\author{
Muhamad Ajwar ${ }^{1}$, Hardiansyah $^{2}$, Mariamah $^{3, *}$, Syahriani Yulianci ${ }^{4}$ \\ 1,2,3,4 STKIP Taman Siswa Bima

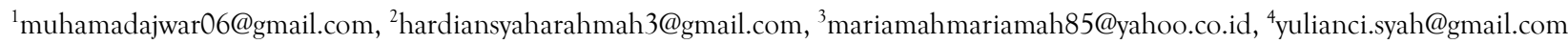 \\ ${ }^{*}$ Corresponding Author
}

Artikel Info

Tanggal Publikasi

2019-06-30

Kata Kunci

Open Ended

Kreativitas

\begin{abstract}
Abstrak
Terdapat beberapa permaslahan yang peneliti temukan sebagi dosen pengampu seperti Kreativitas mahasiswa dalam menyelesaikan masalah masih rendah serta kemampuan pemecahan masalah masih kurang sehingga penelitian ini bertujuan untuk menerapkan pembelajaran open-ended untuk meningkatkan kreativitas belajar dan kemampuan pemecahan masalah mahasiswa pada mata kuliah Konsep Dasar IPA SD pada jurusan PGSD di STKIP Taman Siswa Bima. Jenis penelitian ini adalah penelitian ekperimen. Adapun desain penelitian adalah pemberian pre test sebelum perlakukan dan postest setelah perlakuan. Pengambilan sampel dilakukan secara random sapling. Intrumen yang digunakan dalam penelitian ini adalah intrumen tes dan angket. Penganalisian data menggunakan uji-t pada tarf signifikan $5 \%$. Berdasarkan hasil perhitungan dengan menggunakan SPSS. 16 dengan jenis uji independen test didapat nilai $\mathrm{t}$ hitung (equal variance assumed) adalah 11,14 yang lebih besar dari t tabel $(2,39)$. Sehingga dapat disimpulkan bahwa open ended berpengaruh terhadap kreativitas.
\end{abstract}

\section{PENDAHULUAN}

Ilmu Pengetahuan Alam merupakan salah satu mata pelajaran yang sangat penting dalam pendidikan, karena IPA memuat materi-materi yang bekaitan langsung dengan kehidupan sehari-hari manusia di bumi dan luar angkasa. Akibat begitu pentingnya, diharapkan para mahasiswa sebagai calon guru SD dapat menguasai materi-materi IPA melalui pembelajaran inovatif dan menyenangkan. Untuk menyiapkan calon guru IPA di Sekolah Dasar yang kreatif dan mampu memecahkan berbagai masalah, di STKIP Taman Siswa Bima telah menyediakan jurusan Pendidikan Guru Sekolah Dasar (PGSD). Salah satu permasalahan besar yang peneliti hadapi pada mata kuliah Konsep Dasar IPA SD adalah kurangnya kreativitas mahasiswa dalam pembelajaran, mahasiswa hanya terbiasa dengan soalsoal rutin, penyelesaian masalah yang bersifat kaku. Untuk mengatasi masalh tersebut, maka solusi yang diambil adalah menerapkan Open ended. Open ended merupakan metode mengajar yang menerapkan permasalahan terbuka dan berbagai cara penyelesaian masalah. Model Open Ended merupakan suatu pendekatan pembelajaran yang dimulai dari mengenal atau menghadapkan mahasiswa pada masalah terbuka, kemudain dilanjutkan dengan menggunakan banyak jawaban benar dari permasalahan yang diberikan. Hal ini memberikan pengalaman kepada mahasiswa untuk menemukan sesuatu yang baru di dalam proses pembelajaran. Sedangkan bahwa model Open Ended adalah pembelajaran dengan menyajikan suatu permasalahan yang mempunyai metode atau penyelesaian yang benar lebih dari satu, sehingga menciptakan mahasiswa yang kreatif. Selain mahasiswa menjadi kreatif, open ended juga dapat meningkatkan kemampuan pemecahan masalah mahasiswa.

Dalam kehidupan manusia, kreativitas sangat penting sebab merupakan suatu kemampuan yang sangat diperlukan dalam proses menciptakan sesuatu yang baru untuk memenuhi kebutuhan 
hidup. Kreativitas juga merupakan salah satu kebutuhan pokok manusia, yakni kebutuhan akan perwujudan diri (aktualisasi diri) dan merupakan kebutuhan paling tinggi bagi manusia. Pada dasarnya, setiap manusia dilahirkan di dunia dengan memiliki potensi kreativitas masing-masing. Kreativitas dapat diidentifikasi dan dipupuk melalui pendidikan yang tepat. Berdasarkan pendapat tersebut, potensi kreativitas setiap orang akan didapat melalui pembelajaran secara kontinuitas sampai dapat menciptakan sesuatu yang berguna dan menjadi sebuah pemecahan masalah yang dihadapi. Membahas tentang konsep kreativitas merupakan titik pertemuan yang khas antara tiga atribut psikologis intelegensi, gaya kognitif, dan kepribadian/motivasi, bersama-sama ketiga segi dari alam pikiran ini membantu memahami apa yang melatar belakangi individu yang kreatif. Intelegensi meliputi terutama kemampuan verbal, pemikiran lancar, pengetahuan perencanaan, perumusan masalah penyusunan strategi representasi mental, keterampilan mengambil keputusan dan keseimbangan serta integrasi intelektual secara umum. Gaya kognitif atau intelektual dari pribadi yang kreatif menunjukkan kelonggaran dari keterikatan pada konfensi menciptakan aturan sendiri dalam melakukan hal-hal dengan ceranya sendiri, menyukai masalah yang tidak terlalu terstruktur senang menulis, merancang, lebih tertarik pada jabatan yang kreatif seperti mengarang saintis atau arsitek. Kreativitas berhubungan dengan penemuan sesuatu, mengenai hal yang menghasilkan sesuatu yang baru dengan menggunakan sesuatu yang talah ada. Dalam hal ini, sesuatu yang baru itu berupa perbuatan atau tingkah laku, benda, bangunan yang individu ciptakan dengan menggunakan potensi kreativitas yang dimiliki. Ciri-ciri dari kreativitas antara : 1) Kelancaran berfikir (fluency of thinking), yaitu kemampuan untuk menghasilkan banyak ide yang keluar dari pemikiran seseorang secara cepat. 2) Keluwesan berfikir (flexibility), yaitu kemampuan untuk memproduksi sejumlah ide, jawabanjawaban atau pertanyaan-pertanyaan yang bervariasi, dapat melihat suatu masalah dari sudut pandang yang berbeda-beda, mencari alternative atau arah yang berbeda beda, serta mampu menggunakan bermacam-maca pendekatan atau cara pemikiran. 3) Elaborasi (elabotation), yaitu kemampuan dalam mengembangkan gagasan dan menambah atau memperinci detail-detail dari suatu objek, gagasan atau situasi sehingga menjadi lebih menarik. 4) Originalitas (originality), yaitu kemampuan untuk mencetuskan gagasan unik atau kemampuan untuk mencetuskan gagasan asli. Jika ciri-ciri di atas dapat dimiliki oleh seseorang, maka orang tersebut dapat dikatakan kreatif (Munandar, Utami : 1999). Pengenalan kreativitas kepada proses perancangan sistem pembelajaran adalah salah satu usaha yang mendukung pergeseran paradigm, merupakan factor yang penting untuk menghubungkan berbagai pemikiran di balik pergeseran paradigma, dalam rangka mengembangkan secara optimal kekritisan dan pemikiran kreatif mahasiswa. Jika pendidikan tinggi berfungsi untuk mempromosikan kreativitas, maka harus mencerminkan kenyataan tentang para mahasiswanya, mendiskusikan bagaimana kenyataan ini dapat digunakan untuk meningkatkan kreativitas, seperti halnya terlibat dalam aktivitas yang mendorong kreativitas. Anderson mengeksplorasi lebih lanjut pentingnya kreativitas dalam pendidikan tinggi, dengan mendukung bahwa pengalaman mahasiswa seharusnya meliputi kesempatan untuk menemukan potensi seseorang dan mencapai tingkat yang lebih tinggi dari ekspresi kreatif (Rosmawati: 2018)

\section{METODE}

Adapun jenis penelitian ini adalah penelitian eksperimen. Dimana metode yang dijadikan eksperimen adalah penerapan open ended. Berikut ini diuraikan desain penelitian yang digunakan

Tabel 2.1. Desain penelitian

\begin{tabular}{lll}
\hline Pre test kelas eksperimen & Perlakuan & Post test kelas eksperimen \\
\hline Pre test kelas kontrol & - & Post test kelas kontrol \\
\hline
\end{tabular}


Adapun tahapan penelitian dapat diuraikan sebagai berikut:

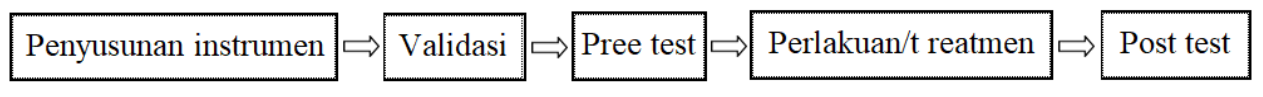

Tempat penelitian dilakukan di STKIP Taman Siswa Bima pada semester genap tahun akademik 2018/2019. Populasi dari penelitian adalah seluruh mahasiswa semester II yang terdiri dari lima kelas yang berjumlah 210 orang mahasiswa. Sementara sampel penelitian adalah mahasiswa semester II-D dan II-E Sampel diambil secara Random. Teknik dan Instrumen Pengumpulan Data. Analisis Keefektifan Pembelajaran open-ended terhadap peningkatan kreativitas belajar dan kemampuan pemecahan masalah mahasiswa dapat dilihat tahapan berikut mulai dari uji normalitas, uji homogenitas dan uji hipotesis.

\subsection{Uji Normalitas}

Uji normalitas digunakan rumus kolmogorov-smirnov. Keputusan uji dan kesimpulan diambil pada taraf signifikansi 5\% dengan kriteria: 1) jika nilai signifikansi lebih besar dari 0,05 maka $\mathrm{Ha}_{\mathrm{a}}$ diterima, sehingga data berdistribusi normal, begitupun sebaliknya 2) jika nilai signifikansi lebih kecil dari 0,05 maka $\mathrm{H}_{\mathrm{a}}$ ditolak, sehingga data tidak berdistribusi normal. Uji normalitas dalam penelitian ini menggunakan bantuan program software SPSS16 for windows.

\subsection{Uji Homogenitas}

Uji homogenitas menggunakan uji homogenitas Box-M bantuan program SPSS 16 for window. Uji homogenitas dan penarikan Kesimpulan terhadap uji hipotesis dilakukan pada taraf signifikansi 5\%. Pedoman pengambilan keputusan apabila: 1) nilai signifikansi atau nilai probabilitas kurang dari 0,05 data tidak homogen, dan 2) nilai signifikansi atau nilai probabilitas lebih dari 0,05 maka data homogen.

\subsection{Uji hipotesis}

Untuk menguji Hipotesis penelitian menggunakan statistik uji- t. Dengan bantuan software SPSS 16 for window. Kriteria pengujiannya adalah HO ditolak jika nilai signifikansi lebih kecil 0.05. adapun rumus uji- $\mathrm{t}$ sebagai berikut:

Adapun kriteria penolakan dan penerimaan dari hipotesis dalam penelitian ini dengan taraf kepercayaan $5 \%$ apabila nilai t-hitung lebih besar dari t-tabel maka $\mathrm{Ha}_{a}$ diterima, begitupun sebaliknya apabila thitung lebih kecil dari t tabel maka $\mathrm{H}_{\mathrm{o}}$ diterima. Sebelum analisis statistik dengan menggunakan uji-t. Terlebih dahulu dilakukan uji prasyarat analisis yaitu uji normalitas data dan uji homogenitas. Uji normalitas data dapat menggunakan bantuan program SPSS.

\section{HASIL PENELITIAN DAN PEMBAHASAN}

Berdasarkan hasil penelitian yang sudah dilakasanakan, berikut ini akan disajikan data hasil tes untuk mengukur kemampuan pemecahan masalah serta hasil pembagian angket kreativitas belajar mahasiswa. Kreativitas mahasiswa pada tes awal dengan nilai rata-rata 63 dari total mahasiswa 33 orang. Sedangkan nilai tertinggi 80 dan nilai terendah 45 dalam pengisian angket dengan rentang nilai 35. Nilai rata-rata 87 dari total mahasiswa 33 orang pada tes akhir ini terdapat kenaikan nilai rata-rata dibandingkan nilai pada tes awal. Sedangkan nilai tertinggi 105 dan nilai terendah 70 dalam pengisian angket dengan rentang nilai 35.

Berikut ini akan disajikan nilai dari uji t dengan menggunakan program SPSS.16 pada taraf signifikan 5\%. Pengujian menggunakan uji dua sisi dengan tingkat signifikansi 5\%. Tingkat signifikansi dalam hal ini berarti kita mengambil risiko salah dalam mengambil keputusan untuk 
menolak hipotesis yang benar sebanyak banyaknya 5\% (signifikansi 5\% at: 48 adalah ukuran standar yang sering digunakan dalam penelitian. Dari tabel di atas didapi....... $\mathrm{t}$ hitung (equal variance assumed) adalah 11,14. Tabel distribusi t dicari pada alfa 5\% dengan derajat kebebasan (df) $n$ 2 atau 33-2 = 31. Hasil diperoleh untuk t tabel sebesar 2,039. Maka dapat diketahui bahwa nilai $\mathrm{t}$ hitung lebih besar dari t tabel sehingga hipotesi yang diterima adalah Ha dan Ho ditolak.

$$
t-t e s t=\frac{\bar{X}_{1}-\bar{X}_{2}}{\sqrt{\left(\frac{S D_{1}{ }^{2}}{N_{1}-1}\right)+\left(\frac{S D_{2}{ }^{2}}{N_{2}-1}\right)}}
$$

Untuk uji selanjutnya dilakukan uji one sample test dengan standar KKM untuk aspek kreativitas sebesar 75. Berikut ini ditampilkan hasil perhitungannya. Oleh karena nilai $\mathrm{t}$ hitung $>\mathrm{t}$ tabel $(7.140>2,039)$ maka Ho ditolak, artinya bahwa terdapat pengaruh penggunanaan open ended terhadap kretaivitas mahasiswa. Dengan melihat nilai probabilitas atau nilai signifikan dengan kriteria jika nilai sig lebih besar dari 0,05 maha Ho diterima. Berdasarkan tabel di atas diperoleh nilai sig. sebesar 0,000. Sehingga dapat disimpulkan bahwa nilai signifikan lebih kecil dari 0,05 maha Ho ditolak dan Ha diterima. Terdapat pengaruh open ended terhadap kemampuan kreativitas belajar mahasiswa pada mata kuliah konsep dasar IPA.

Berdasarkan hasil perhitungan dengan menggunakan SPSS. 16 dengan jenis iju independen test didapat nilai t hitung (equal variance assumed) adalah 11,14 yang lebih besar dari t tabel, sehingga disimpulkan bahwa open ended berpengaruh terhadap kreativitas mahasiswa. Open ended merupakan pembelajaran yang menyajikan suatu permasalahan dengan metode penyelesaian yang benar lebih dari satu (multi cara penyelesaian), sehingga memberikan kesempatan kepada mahsaiswa untuk memperoleh atau menggunakan pengetahuannya untuk menemukan, mengenali dan memecahkan masalah dengan berbagai cara. Dengan begitu mahasiswa akan kreatif dalam menyelesaikan soal karena open ended ini juga lebih berorentasi pada aktivitas mahasiswa. Dari empat askpek dari kretaivitas, mahasiswa menjadi lancar untuk berfikir (fluency of thinking) dimana kemampuan untuk menghasilkan banyak ide yang keluar dari pemikiran secara cepat dengan menyelesaikan soal multi jawaban. Mahasiswa juga memiliki kemampuan untuk memproduksi sejumlah ide, jawaban-jawaban atau pertanyaan-pertanyaan yang bervariasi, dapat melihat suatu masalah dari sudut pandang yang berbeda-beda, mencari alternative atau arah yang berbeda beda, serta mampu menggunakan bermacam-maca pendekatan atau cara pemikiran. Mahasiswa memiliki kemampuan dalam mengembangkan gagasan dan menambah atau memperinci detail-detail dari suatu objek, gagasan atau situasi sehingga menjadi lebih menarik. Kemampuan Originalitas (originality) mahasiswa menjadi bagus, dimana mahsiswa mampu untuk mencetuskan gagasan unik atau kemampuan untuk mencetuskan

Model Open Ended juga merupakan suatu pendekatan pembelajaran yang dimulai dari mengenal atau menghadapkan mahasiswa pada masalah terbuka, kemudain dilanjutkan dengan menggunakan banyak jawaban benar dari permasalahan yang diberikan sehingga mendorong mahasiswa untuk kreatif dalam mencari berbagai solusi penyelesaian masalah (Arsyad, dkk: 2013) Hal ini memberikan pengalaman kepada mahasiswa untuk menemukan sesuatu yang baru di dalam proses pembelajaran. Sedangkan bahwa model Open Ended adalah pembelajaran dengan menyajikan suatu permasalahan yang mempunyai metode atau penyelesaian yang benar lebih dari satu, sehingga menciptakan mahasiswa yang kreatif. Selain mahasiswa menjadi kreatif, open ended juga dapat meningkatkan kemampuan pemecahan masalah mahasiswa (Suherman : 2003) 


\section{KESIMPULAN}

Hasil uji dengan menggunakan SPSS diperoleh nilai $t$ hitung sebesar 3,53 dan jika dibandingkan denga $t$ tabel maka $t$ hitung $>$ t tabel $(3.53>2,039)$ maka Ho ditolak, artinya bahwa terdapat pengaruh penggunanaan open ended terhadap kemampuan pemecahan masalah mahasiswa. Dengan melihat nilai probabilitas atau nilai signifikan dengan kriteria jika nilai sig lebih besar dari 0,05 maha Ho diterima. Berdasarkan tabel di atas diperoleh nilai sig. sebesar 0,489. Sehingga dapat disimpulkan bahwa nilai signifikan lebih kecil dari 0,05 maha Ho ditolak dan Ha diterima. Terdapat pengaruh open ended terhadap kemampuan pemecahan masalah mahasiswa pada mata kuliah konsep dasar IPA.

\section{Daftar Pustaka}

Arsad HS, Dwi NS, Winanda Marito. 2013. Pendekatan Open Ended Problem. Prosiding Seminar Nasional.

Munandar, Utami (1999) Kreativitas dan Keberbakatan, Strategi Mewujudkan Potensi Kreatif dan Bakat, Jakarta: Gramedia

Rosmawati, dkk. Kemmapuan pemecahan masalah dan lembar kerja siswa berbasis problem solving. Jurnal pendidikan matematika vol.1 nomor 1. [Online]. Tersedia di: http://ejournal.unp.ac.id/pmat/article/download/1227/. Diunduh pada tanggal 23 Juli 2018.

Suherman, Erman dkk. 2003. Strategi Pembelajaran Matematika Kontemporer. Bandung: PT Remaja Rosdakarya. 